\title{
Population structure, growth and production of Thoracophelia furcifera (Polychaeta: Opheliidae) on a sandy beach in Southern Brazil
}

\author{
Mariana B. P. Otegui - Arno Blankensteyn • \\ Paulo R. Pagliosa
}

Received: 21 July 2011/Revised: 27 October 2011/Accepted: 31 October 2011/Published online: 15 November 2011

(C) Springer-Verlag and AWI 2011

\begin{abstract}
This study investigates aspects of the life history of the polychaete Thoracophelia furcifera on a sandy beach in southern Brazil. Two fixed transects perpendicular to the shoreline in the intertidal zone were sampled fortnightly from May 2008 to April 2009 at low tide. Five T. furcifera samples were collected along each transect and sediment temperature and the salinity of interstitial water were recorded. The material was washed over 0.5 - and $0.088-\mathrm{mm}$ sieves, and the width of setiger 8 of each specimen was measured. A total of 5,870 organisms were examined and the estimated parameters of the von Bertalanffy growth curve were $L_{\infty} 3.60 \mathrm{~mm}$ (Wd8S), $K$ 0.63 year $^{-1}, C 0.3$ and WP 0.97 (Rn 0.132). Life span was 2.6 years, instantaneous mortality rate $Z$ was 3.8 year $^{-1}$ and the growth index $\varphi^{\prime} 0.91$. Mean density ranged from $644.44 \pm 191.77$ to $2,783.33 \pm 453.64$ ind $\mathrm{m}^{-2}$ and mean biomass ranged from $2.52 \pm 0.55$ to $9.52 \pm 1.83 \mathrm{~g} \mathrm{~m}^{-2}$. Recruitment occurred from April to July and ovigerous females were found from June to November. Annual secondary production was $6.582 \mathrm{~g} \mathrm{~m}^{-2}$ year $^{-1}$, mean biomass was $5.638 \mathrm{~g} \mathrm{~m}^{-2}$ and turnover rate was 1.167 . The high values for density, secondary production and biomass
\end{abstract}

M. B. P. Otegui $(\bowtie)$ · P. R. Pagliosa

Centro de Ciências Biológicas, Núcleo de Estudos do Mar, Universidade Federal de Santa Catarina, Florianópolis, SC 88040-900, Brazil

e-mail: marianabpaz@yahoo.com.br

\section{A. Blankensteyn}

Departamento de Ecologia e Zoologia,

Centro de Ciências Biológicas, Laboratório de Fauna Bentônica

Marinha, Universidade Federal de Santa Catarina,

Florianópolis, SC, Brazil suggest that $T$. furcifera constitute an important food source. These features of T. furcifera' life strategy demonstrate the significant role this species plays in ecosystem dynamics.

Keywords Sandy beaches - Life history $\cdot$ Population dynamics · Life span · Polychaeta - Opheliidae - Euzonus

\section{Introduction}

Sandy beaches are dynamic ecosystems defined by three factors: tides, waves and sands (McLachlan and Brown 2006). These environments present a wide spectrum of size, morphologies, extent of exposure and oceanographic conditions, resulting in a high diversity of biological characteristics (Schlacher et al. 2008). Changes and gradients in the physical environment explain much of the variation found in the community structure of sandy beaches. This has been demonstrated by the increased species richness and diversity observed at dissipative beaches when compared with harsh reflective beaches (Defeo and McLachlan 2011). Furthermore, although the world's temperate and tropical coastlines are dominated by sandy beaches, their benthic macrofauna diversity has received little attention. Present and future research will be centered on the role of physical and biological factors in population dynamics.

Knowledge of the life histories of invertebrates inhabiting sandy beaches is important to understand the species' ecological roles and their importance to the ecosystem. The allocation of net energy to reproduction and growth also constitutes a fundamental life history trait of a population (Roff 1992). Studies of population dynamics require evaluation of growth parameters, recruitment patterns, the number of cohorts per year, organism life span, mortality, 
population biomass and production. Such studies provide a basis for measuring energy transfer and assessing the role populations play in communities and, as such, aid rational management (Tumbiolo and Downing 1994) and monitoring of benthic communities (Wilber and Clarke 1998).

Macrobenthic communities constitute an important link in the energy flow of coastal ecosystems (Martin and Bastida 2006). It is important to assess the population dynamics of polychaetes because this group of organisms exhibits high diversity, density, biomass and production (Knox 1977). Furthermore, they constitute an important food resource for carnivorous residents and visitors such as other polychaetes (Martin and Bastida 2006), crustaceans (Petti et al. 1996; Martin and Bastida 2006), fishes (Amaral et al. 1994; Martin and Bastida 2006) and birds (Schneider and Harrington 1981; Martin and Bastida 2006).

Polychaetes of the Opheliidae family inhabit the intertidal zone of subtropical and temperate sandy beaches worldwide (Souza and Borzone 2007). They are considered burrowers into sandy and/or muddy sediments, and are usually classified as non-selective deposit feeders (Fauchald and Jumars 1979). Their carbon source is bacteria and other microbes and their consumption of organic matter varies between different ecosystems (Kemp 1986). An apparent absence of feeding specialization contrasts with a high degree of substrate selectivity, as most species of the genus Thoracophelia are restricted to sediments with little variation in grain size (Dales 1952). Polychaetes of the genus Thoracophelia are the most representative macrofauna elements in the upper and mid-intertidal zones of southern Brazil (Neves et al. 2007) and are one of the main species responsible for nutrient recycling in these systems (Gordon 1960).

Thoracophelia furcifera (Ehlers, 1897) (taxon name according to Blake 2011) is an opheliid polychaete with a range from $52^{\circ} \mathrm{S}$ in the Strait of Magellan (Orensanz and Gianuca 1974) to $23^{\circ} \mathrm{S}$ in southeast Brazil (Veloso et al. 2003a). It is considered an abundant species in dissipative sandy beaches with fine grain and well-sorted sands (Souza and Gianuca 1995; Borzone et al. 1996; Barros et al. 2001) and an indicator of environmental disturbance (Seike 2008; Bergamino et al. 2009). These polychaetes perform chemical and physical remobilization of the sediment and their secondary production may be as high as that of cooccurring populations of filter feeder (Dangott and Terwilliger 1986). Despite of their ecological importance, few studies on its biology and life history exist.

The aim of the present study was to estimate the population parameters and secondary production of the T. furcifera on a sandy beach in southern Brazil, thereby contributing data on the role this species plays in its community.

\section{Materials and methods}

Study area

The study was conducted at Barra da Lagoa Beach, which is located at $27^{\circ} 34^{\prime} 421^{\prime \prime} \mathrm{S}$ and $48^{\circ} 25^{\prime} 377^{\prime \prime} \mathrm{W}$ in southern Brazil (Fig. 1). Barra da Lagoa Beach can be classified as having intermediate morphodynamics, with well-selected grains predominantly composed of fine sand and a low to moderate slope and ranges from sheltered though exposed to high wave energy, depending on wind direction (Horn Filho 2006). Sediment temperature in the area sampled ranged from $12.5^{\circ} \mathrm{C}$ in June to $25^{\circ} \mathrm{C}$ in February and March. Interstitial salinity ranged from 26 in November to 39 in August and April.

Sampling and laboratory procedures

Sampling was carried out fortnightly during spring tides from May 2008 to April 2009 along two fixed transects perpendicular to the Barra da Lagoa Beach shoreline approximately $300 \mathrm{~m}$ apart. The method of "species-driven" sampling was employed, where sampling is restricted

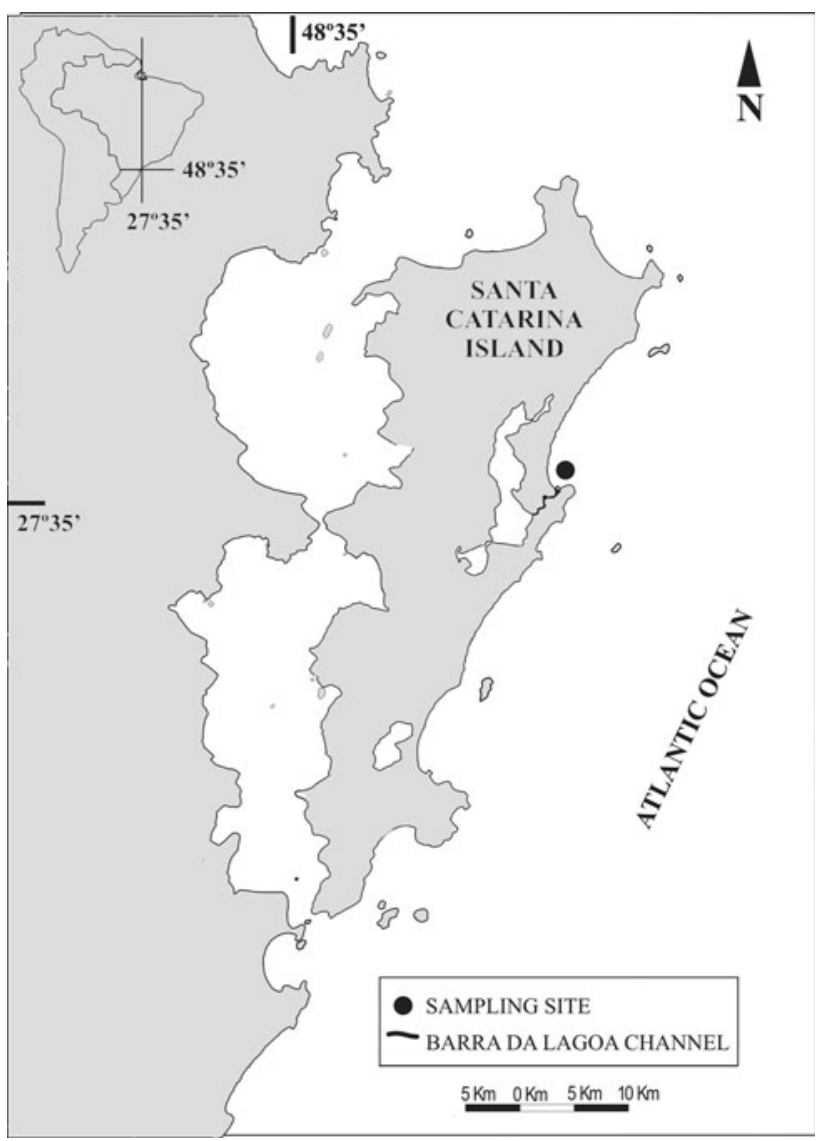

Fig. 1 Sampling site (filled circle) at Barra da Lagoa Beach, southern Brazil 
to the spatial range of a species. Five random samples of $0.018 \mathrm{~m}^{2}$ were taken down to a depth of $20 \mathrm{~cm}$ along each transect. For each sample, random allocation sampling was performed along the entire across-shore distribution of the species, up to the point at which at least some consecutive sampling units did not contain Thoracophelia individuals (Defeo and Rueda 2002). Sediment temperature was recorded with a thermometer $\left(0.1^{\circ} \mathrm{C}\right)$ and interstitial salinity was recorded with a refractometer (1 psu).

Samples were sieved with 0.5 and $0.088 \mathrm{~mm}$ meshes in the laboratory and T. furcifera specimens retained were separated, counted and fixed in $10 \%$ formalin for $48 \mathrm{~h}$ and then preserved in $70 \%$ alcohol. Sexually mature females were identified and quantified by the presence of oocytes in the coelom, visible through the transparent body wall. The width of each individual was measured at setiger 8 (Wd8S) (Souza and Borzone 2007) using a ruler $(0.1 \mathrm{~mm})$ coupled to the ocular lens of a stereoscopic microscope. Seventy specimens of $T$. furcifera of different size classes were dried individually at $60^{\circ} \mathrm{C}$ for $48 \mathrm{~h}$ or until reaching constant weight, then weighed to the nearest $0.0001 \mathrm{~g}$ (Bioprecisa FA2014 balance). They were then ignited at $500^{\circ} \mathrm{C}$ for $4 \mathrm{~h}$ and weighed again. Ash-free dry weight (AFDW) was obtained by subtracting the second weight from the first.

\section{Data analysis}

Data from both sampling sites were grouped for each date sampled for the purposes of population parameter analysis. Temporal variation of density was tested using one-way ANOVA. The Bhattacharya method was used to identify the modes (cohorts) (Bhattacharya 1967) and the growth parameters of the von Bertalanffy Growth Function (VBGF) were based on analysis of $0.1 \mathrm{~mm}$ size (Wd8S) frequency distributions. The VBGF was estimated with the ELEFAN I routine that is part of the FISAT II software package (Gayanilo and Pauly 1997) using the von Bertalanffy model with seasonal oscillation (Pauly and Gaschutz 1979):

$\left.L_{t}=L_{\infty}\left[1-e^{-\left[k\left(t-t_{0}\right)+\frac{C K}{2 \pi}\left(\operatorname{sen} 2 \pi\left(t-t_{s}\right)-\operatorname{sen} 2 \pi\left(t_{0}-t_{s}\right)\right)\right.}\right]\right]$

where $L_{t}$ is length (Wd8S) at time $t(\mathrm{~mm}) ; L_{\infty}$ is the maximum asymptotic length (Wd8S); $K$ is the growth coefficient; $C$ is the parameter reflecting the intensity of seasonal oscillation; and $t_{s}$ is the beginning of the sinusoid growth oscillation relative to $t=0$ and is related to the "winter point" (WP), which is the moment of lowest growth, expressed as a decimal fraction of the year $\left(\mathrm{WP}=t_{s}+0.5\right)$. The goodness of fit index $(\mathrm{Rn})$ was used to assess the combination of the parameters calculated: the higher the $\mathrm{Rn}$, the better the fit of the growth model. The value for $\mathrm{t}_{0}$ was estimated on the basis of the smallest width found. The phi prime growth index $\varphi^{\prime}=2 \log _{10}$ $L_{\infty}(\mathrm{Wd} 8 \mathrm{~S})+\log _{10} K$ (Pauly and Munro 1984) was used to measure growth performance. Life span was estimated using the Wd8S containing 99\% of the population (Alagaraja 1984; Defeo and Cardoso 2002). The instantaneous mortality rate $(\mathrm{Z})$ was estimated using the length-converted catch curve (Pauly 1983).

Total annual secondary production was calculated using the mass-specific growth rate method (MSGRM) (Crisp 1984):

$P=\Sigma N_{i} M_{i} G_{i}\left(\mathrm{~g}_{\mathrm{gFDW} \mathrm{m}}^{-2}\right.$ year $\left.^{-1}\right)$

where $N_{i}$ is the mean number of individuals in size class $i$ per square meter; $M_{i}$ is the mean individual mass in size class $i$, and $G_{i}$ is the specific growth rate in annual mass, given by:

$G_{i}=b \times K \times\left[\left(\frac{L_{\infty}}{L_{t}}\right)-1\right]\left(\right.$ year $\left.^{-1}\right)$

where $b$ is the exponent of the mass-length relation and $L_{t}$ is the average length in class $t$.

Annual mean biomass was estimated by:

$\bar{B}=\Sigma N_{i} M_{i}\left(\mathrm{~g} \mathrm{AFDW} \mathrm{m}^{-2}\right)$

The turnover rate of the $T$. furcifera population was calculated using the ratio between total annual production $P$ and the annual mean biomass $\bar{B}$.

\section{Results}

No specimens of $T$. furcifera were found after straining through the $0.088-\mathrm{mm}$ mesh. Using the $0.5-\mathrm{mm}$ mesh, 5,870 individuals were collected. Sizes (Wd8S) ranged from $0.40 \mathrm{~mm}$ in the second fortnight of May to $3.40 \mathrm{~mm}$ in the first fortnight of July. Annual mean density $( \pm \mathrm{SE})$ was $1,630.56 \pm 648.32$ ind $\mathrm{m}^{-2}$ and fortnightly mean density (ANOVA; $F_{9 ; 19}=2.94 ; P<0.001$ ) ranged from

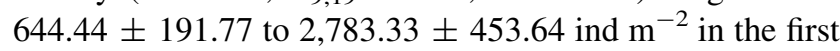
fortnights of July and January respectively (Fig. 2). The studied population of $T$. furcifera exhibited one annual cohort and a bimodal population structure from the first fortnight of April to the first fortnight of November, and a unimodal structure in the remainder of the year (Fig. 3).

A total of 350 ovigerous females were observed between June and November (except in July, when no ovigerous specimens were found). The percentage of ovigerous females in the population ranged from $0.29 \%$ (1 ind.) in June to $44 \%$ (154 ind.) in October. Ovigerous females were found in the size classes from 1.6 to 2.9 (Wd8S), with a peak in the $2.1-\mathrm{mm}$ class $(24.85 \%, 87$ ind.). Recruitment of 
Fig. 2 Fortnightly variation in density (open circle) and biomass (open box) (mean $\pm \mathrm{SE}$ ) of the T. furcifera population at Barra da Lagoa Beach, southern Brazil, from May 2008 to April 2009: "I" refers to the first fortnight of the month, and "II" to the second one

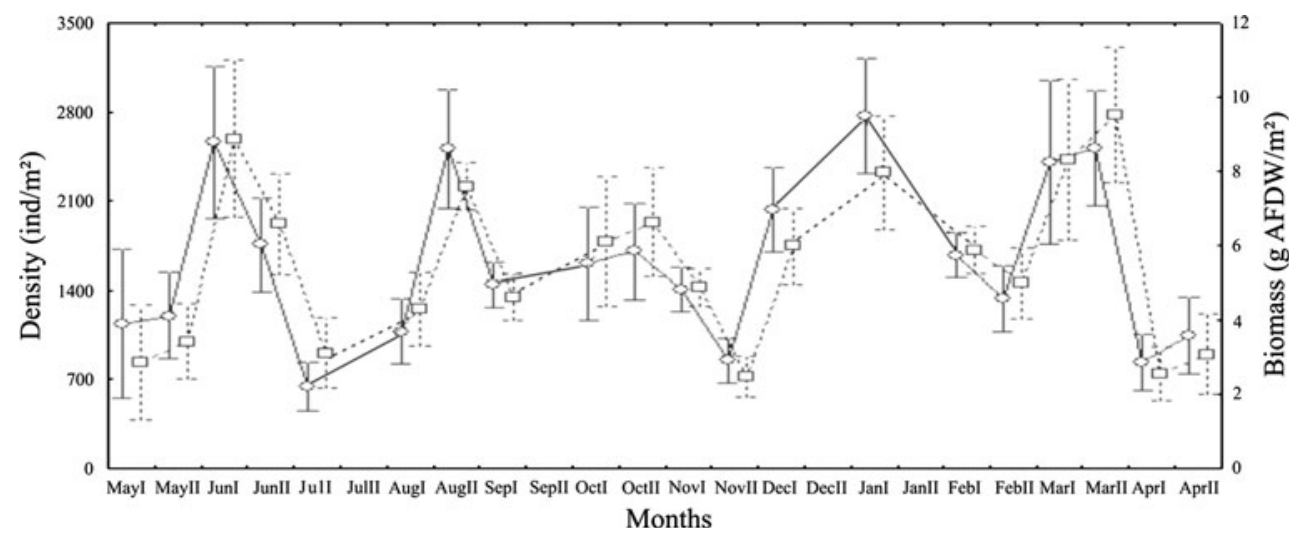

T. furcifera was found from April to July, with the percentage of juveniles in the population ranging between $7.70 \%$ in May and $43.85 \%$ in April (Fig. 4a, b).

The growth parameters estimated by VBGF were $L_{\infty}=3.60 \mathrm{~mm} \quad(\mathrm{Wd} 8 \mathrm{~S}), \quad K=0.63$ year $^{-1}, \quad C=0.3$, $\mathrm{WP}=0.97(\mathrm{Rn}=0.132)\left(\right.$ Fig. 5) and $\mathrm{t}_{0}$ was $0.4 \mathrm{~mm}$. The growth index phi prime $\varphi^{\prime}$ was 0.91 , life span 2.6 years, and the instantaneous mortality rate $\mathrm{Z} 3.8$ year $^{-1}$. The relation between width (Wd8S) and ash-free dry weight was $y=0.0005 x^{2.4631}\left(r^{2}=0.78 ; P<0.001 ; n=70\right)$. Total annual secondary production was $6.582 \mathrm{~g} \mathrm{~m}^{-2}$ year $^{-1}$. Annual mean biomass was $5.638 \mathrm{~g} \mathrm{~m}^{-2}$ and the fortnightly mean biomass $( \pm \mathrm{SE})$ ranged from $2.52 \pm 0.55$ to $9.52 \pm 1.83 \mathrm{~g} \mathrm{~m}^{-2}$ in the second fortnights of November and March respectively (Fig. 2). Turnover rate was 1.167.

\section{Discussion}

The population density of $T$. furcifera at Barra da Lagoa fluctuated over time and was higher than densities that have been reported for other sandy beaches in this species' biogeographical range. The mean population density in this study was 3 to 2,000 times greater than on other beaches from southern Brazil to Uruguay (Table 1). A similar pattern of fluctuation in density and biomass was found in other T. furcifera populations, such as the population of Atami Beach (Souza and Borzone 2007), and also in populations of other intertidal polychaetes, such as Scolelepis squamata (Müller, 1806) and Laeonereis culveri (Webster, 1879) (Souza and Borzone 2000; Martín and Batista 2006), as well as in populations of crustaceans such as Emerita brasiliensis (Schmitt, 1935), Excirolana brasiliensis (Dana, 1853), E. armata (Dana, 1853) and Pseudorchestoidea brasiliensis (Dana, 1853) (Defeo et al. 1997; Cardoso et al. 2003; Veloso et al. 2003b; Petracco et al. 2010) and bivalves Donax hanleyanus (Philippi, 1842) and Mesodesma mactroides (Deshayes, 1854) (Defeo and Alava 1995; Brazeiro and Defeo 1999). This common feature of beach macrofaunal populations may be associated with biological factors such as recruitment (Veloso and Cardoso 1999), high mortality and migration (McLachlan and Brown 2006) as well as with physical factors such as slope (Caetano et al. 2003), salinity, temperature (Leber, 1982) and beach morphodynamics (McLachlan and Brown 2006).

Recruitment in the studied $T$. furcifera population resulted in an annual cohort. A similar observation was made for a population of this species at Atami Beach (Souza and Borzone 2007). There was a single, seasonally well restricted reproductive bout per year. Ovigerous females were found in the months following the recruitment period. Approximately $50 \%$ of the ovigerous females ranked among the size classes from 2.1 to $2.2 \mathrm{~mm}$ (Wd8S).

The reproductive strategy of $T$. furcifera differs from that of many other polychaetes. Polychaetes of the family Spionidae, such as Scolelepis gaucha (Orensanz \& Gianuca, 1974), S. squamata, S. goodbodyi (Jones, 1962) and S. chilensis (Hartmann-Schröder, 1962) have a short gametogenic cycle and a reproductive period spanning virtually the whole year (Santos 1994; Souza and Borzone 2000; MacCord and Amaral 2007). Similar results have been reported for Streblospio gynobranchiata (Rice \& Levin, 1998) (Taheri et al. 2009) and S. shrubsolii (Buchanan, 1890) (Kevrekidis 2005) and for the serpulids Pomatoceros triqueter (Linnaeus, 1767) and P. lamarckii (Quatrefages, 1866) (Cotter et al. 2003). This difference seems to be associated with the size of individuals, since small organisms do not have enough room to produce a large number of eggs in a single spawning and therefore tend towards continuous reproduction (Giangrande 1997). On the other hand, many species of the family Nereididae, which have a larger body size, also exhibit a prolonged recruitment period with successive cohorts over the year (Klesch 1970; Gillet 1990; Choi and Lee 1997; Abrantes et al.1999; Omena and Amaral 2000; Gillet and Torressani 2003; Martin and Bastida 2006; Gillet et al. 2008). Nereis oligohalina (Rioja, 1946), for instance, has four annual cohorts (Pagliosa and Lana 2000). There is an 

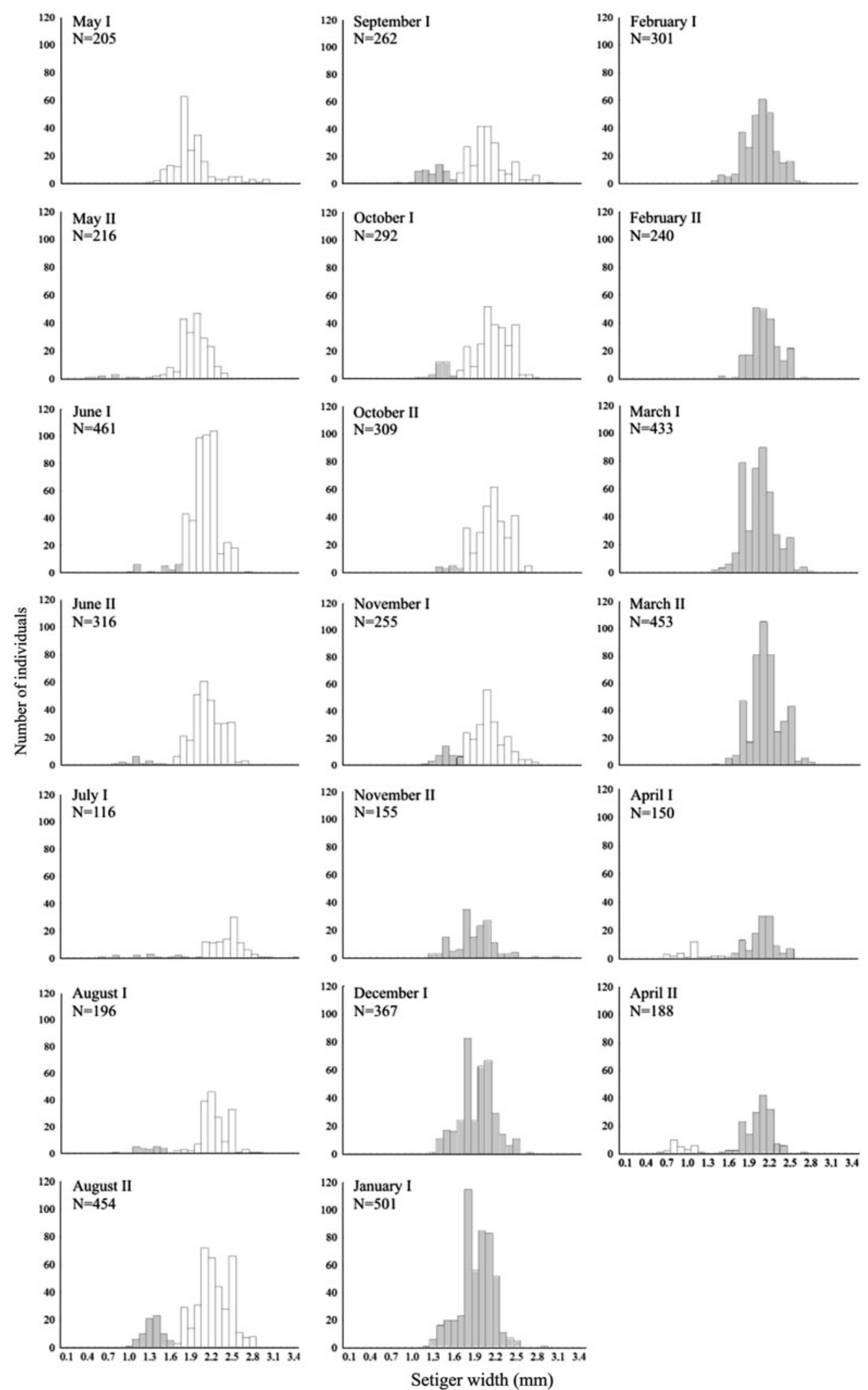

Fig. 3 Histogram of fortnightly frequency distribution of size classes (Wd8S) and cohorts of the T. furcifera population at Barra da Lagoa Beach, southern Brazil, from May 2008 to April 2009. Grey bars represent the new cohort in the population 

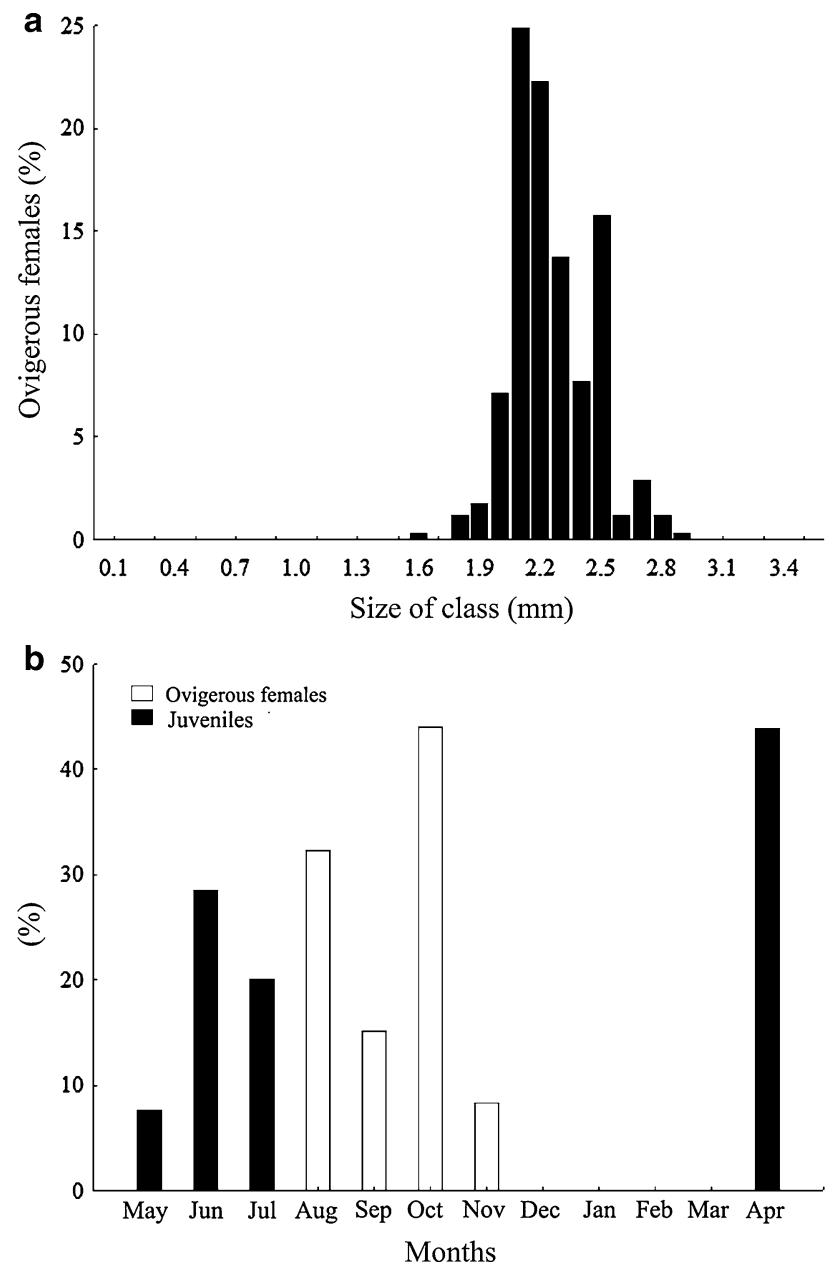

Fig. 4 Percentage of ovigerous females and juveniles of T. furcifera in the Barra da Lagoa Beach population, southern Brazil, from May 2008 to April 2009: a frequency distribution of ovigerous females by size class; $\mathbf{b}$ monthly variation in percentages of ovigerous females and juveniles

allocation of energy between reproduction and growth, and as the reproductive effort in increased, body size will decrease, indicating that body size is of fundamental importance in determining life strategies (Cassai and Prevedelli 1999; Prevedelli and Simonini 2003).
The growth pattern of $T$. furcifera in this study was characterized by a rapid initial increase in body size (Wd8S) (Fig. 5). However, the growth rate decreases by $30 \%$ towards the end of year (WP $=0.93$ ), corresponding with an increase in reproductive effort. Somatic growth decreases as soon as gamete development starts (CuzinRoudy 1993). However, different from what was reported for the Atami Beach population (Souza and Borzone 2007), body growth did not cease in this study's population, which continued to allocate energy to growth even during the reproductive period.

Overall, the population parameters exhibited by the Barra da Lagoa population were slightly higher than those found in the Atami Beach population studied by Souza and Borzone (2007). In the former, individuals $>2.32 \mathrm{~mm}$ Wd8S were observed which is above the maximum asymptotic value found the Atami Beach population. The growth index was also higher in the present study, indicating that growth performance of the Atami Beach population is lower than the species' development potential. The instantaneous mortality rate of the two populations was similar, but the life span of individuals of the population studied was longer than that of individuals of the Atami Beach (Table 2). This difference in life span values may be explained by the larger body size of individuals of the studied population.

Barra da Lagoa Beach is under the influence of erosion processes caused by waves, currents, tides and winds (Leal 1999). However, this beach can be considered a sheltered environment, protected from the great S-SE swells, while exposed to the more frequent NE swells (Simó and Horn Filho 2004). On such beaches, which tend to protect macroinfaunal organisms (McLachlan and Brown 2006), polychaetes generally display higher abundance and richness than other taxa (Dexter 1983, 1984; Jaramillo and Gonzales 1991).

The beach studied obviously provides favourable conditions for the development of the T. furcifera population. Besides its sheltered nature, the beach has fine sediment, which is preferred by the species (Borzone et al. 1996; Barros et al. 2001). Another important factor is that Barra
Fig. 5 Von Bertalanffy growth curve (width at setiger 8 ) for the T. furcifera population at Barra da Lagoa Beach, southern Brazil, from May 2008 to April 2009

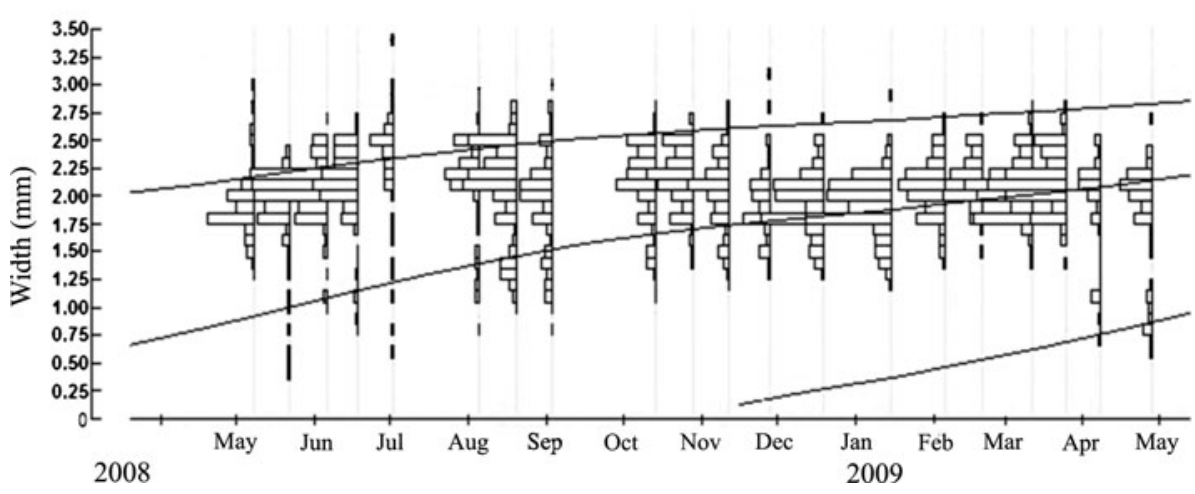


Table 1 A comparison of estimates of mean density (ind $\mathrm{m}^{-2}$ ) for T. furcifera along the species' geographic range of distribution

\begin{tabular}{llcc}
\hline Site & Location & $\begin{array}{l}\text { Mean density } \\
\text { (ind } \mathrm{m}^{-2} \text { ) }\end{array}$ & Source \\
\hline Barra del Chuy Beach (UY) & $33^{\circ} 45^{\prime} \mathrm{S}$ and $53^{\circ} 27^{\prime} \mathrm{W}$ & 567.00 & Defeo et al. (1992) \\
Cassino Beach (BR) & $32^{\circ} 11^{\prime} \mathrm{S}$ and $52^{\circ} 09^{\prime} \mathrm{W}$ & 425.00 & Gianuca (1987) \\
Cassino Beach-Querência (BR) & $32^{\circ} 12^{\prime} \mathrm{S}$ and $52^{\circ} 11^{\prime} \mathrm{W}$ & 65.61 & Silva et al. (2008) \\
Cassino Beach-Altair (BR) & $32^{\circ} 20^{\prime} \mathrm{S}$ and $52^{\circ} 17^{\prime} \mathrm{W}$ & 72.79 & Silva et al. (2008) \\
Atami Beach (BR) & $25^{\circ} 20^{\prime} \mathrm{S}$ and $48^{\circ} 05^{\prime} \mathrm{W}$ & 167.33 & Souza and Borzone (2007) \\
Guaratuba Beach-1 (BR) & $25^{\circ} 53^{\prime} \mathrm{S}$ and $48^{\circ} 34^{\prime} \mathrm{W}$ & 6.00 & Barros et al. (2001) \\
Guaratuba Beach-1 (BR) & $25^{\circ} 53^{\prime} \mathrm{S}$ and $48^{\circ} 34^{\prime} \mathrm{W}$ & 32.20 & Barros et al. (2001) \\
Guaratuba Beach-3 (BR) & $25^{\circ} 52^{\prime} \mathrm{S}$ and $48^{\circ} 34^{\prime} \mathrm{W}$ & 2.30 & Barroset al. (2001) \\
Monte Carlo Beach (BR) & $25^{\circ} 49^{\prime} \mathrm{S}$ and $48^{\circ} 32^{\prime} \mathrm{W}$ & 5.70 & Barroset al. (2001) \\
Itaipu Beach (BR) & $22^{\circ} 58^{\prime} \mathrm{S}$ and $43^{\circ} 02^{\prime} \mathrm{W}$ & 0.80 & Veloso et al. (2003a) \\
Foguete Beach (BR) & $22^{\circ} 58^{\prime} \mathrm{S}$ and $42^{\circ} 01^{\prime} \mathrm{W}$ & 12.80 & Velosoet al. (2003a) \\
Peró Beach (BR) & $22^{\circ} 55^{\prime} \mathrm{S}$ and $42^{\circ} 02^{\prime} \mathrm{W}$ & 3.20 & Veloso et al. (2003a) \\
Barra da Lagoa Beach (BR) & $27^{\circ} 34^{\prime} \mathrm{S}$ and $48^{\circ} 25^{\prime} \mathrm{W}$ & 1630.56 & This study \\
\hline
\end{tabular}

$U Y$ Uruguay, BR Brazil

Table 2 A comparison of estimates of growth parameters, growth index phi prime $\left(\varphi^{\prime}\right)$, instantaneous mortality rate $(Z)$, and life span for different $T$. furcifera populations

\begin{tabular}{lllllllll}
\hline Site & $\begin{array}{l}L_{\infty(\mathrm{Wd} 8 \mathrm{~L})} \\
(\mathrm{mm})\end{array}$ & $K\left(\right.$ year $\left.^{-1}\right)$ & $C$ & WP & $\varphi^{\prime}$ & $Z$ (year $\left.^{-1}\right)$ & $\begin{array}{l}\text { Life span } \\
\text { (years) }\end{array}$ & Source \\
\hline Atami Beach & 2.32 & 0.763 & 1.0 & 0.10 & 0.61 & 3.2 & 1.8 & Souza and Borzone (2007) \\
Barra da Lagoa Beach & 3.60 & 0.630 & 0.3 & 0.93 & 0.91 & 3.8 & 2.6 & This study \\
\hline
\end{tabular}

Table 3 Comparison of estimates of annual secondary production, mean biomass, and turnover rate for different populations of the genus Thoracophelia

\begin{tabular}{llllll}
\hline Species & Site & $P\left(\mathrm{~g} \mathrm{~m}^{-2} \mathrm{year}^{-1}\right)$ & $B\left(\mathrm{~g} \mathrm{~m}^{-2}\right)$ & $P / B$ & Source \\
\hline Thoracophelia mucronata & Oregon Beach (US) & 4.550 & 2.550 & 1.820 & Kemp (1988) \\
Thoracophelia furcifera & Atami Beach (BR) & 0.466 & 0.218 & 2.130 & Souza and Borzone (2007) \\
Thoracophelia furcifera & Barra da Lagoa Beach (BR) & 6.582 & 5.638 & 1.167 & This study \\
\hline
\end{tabular}

US United States, $B R$ Brazil

do Lagoa Channel constantly receives discharges of organically enriched effluents (Pereira 2004) which are transported to the beach by the local hydrodynamics. The combination of beach slope and fine sand favours water retention and consequently increases sediment compaction and contact surface. This, in turn, favours microorganism associations which represent a food source for various deposit feeders (Newell 1965). These favourable environmental conditions may facilitate development and growth of individuals, resulting in larger organisms at higher densities. This again influences individual life span, productivity and biomass.

Annual secondary production and estimated mean biomass of T. furcifera at Barra da Lagoa were higher than at Atami Beach. However, they were similar to those found for T. mucronata on a Pacific beach (Kemp 1988).
Secondary production is not only related to density and growth, but also to biomass and reproduction (Benke 1993), factors which are important in determining the differences between the populations of Barra da Lagoa and Atami. However, the turnover rate, which is an important parameter in comparing different populations and species (Ansell et al. 1978) because it measures the biomass increment rate, shows that biomass increase was smaller in this study (Table 3 ). This occurred because the energy assimilated is used for the production, growth and maintenance of individuals, as shown by the high estimated values for secondary production and biomass.

Overall, we conclude that the T. furcifera population at Barra da Lagoa exhibits a life strategy whereby energy is allocated to a single reproductive bout per year. Under the 
given favourable environmental conditions, high values of population density, growth performance and life span are observed, while biomass varies considerably over time. The high density, secondary production and biomass values encountered suggest that $T$. furcifera constitutes an important food source for inhabitants and visitors of Barra da Lagoa Beach, transferring significant amounts of energy and biomass to higher trophic levels. The species may thus be considered of high importance to ecosystem dynamics, contributing significantly to the structure and maintenance of the macrofaunal benthic community.

Acknowledgments We would like to thank José R. B. Souza, Marcelo Petracco, Humberto Moura Neto, Paulo R. Pezzuto and Lucas T. Frias for their help. The first author received financial support from the Brazilian Research Council (CAPES).

\section{References}

Abrantes A, Pinto F, Moreira MH (1999) Ecology of the polychaete Nereis diversicolor in the Canal de Mira (Ria de Aveiro, Portugal): population dynamics, production and oogenic cycle. Acta Oecol 20:267-283

Alagaraja K (1984) Simple methods for estimation of parameters for assessing exploited fish stocks. Indian J Fish 31:177-208

Amaral ACZ, Nonato EF, Petti MAV (1994) Contribution of the polychaetous annelids to the diet of some Brazilian fishes. Mém Mus Natl Hist Nat 162:331-337

Ansell AD, McLusky DS, Stirling A, Trevallion A (1978) Production and energy flow in the macrobenthos of two sandy beaches in the southwest India. Proc R Soc Edinburgh 76:269-296

Barros F, Borzone CA, Rosso S (2001) Macroinfauna of six beaches near Guaratuba Bay, Southern Brazil. Braz Arch Biol Technol 44:351-364

Benke AC (1993) Concepts and patterns of invertebrate production in running waters. Verh. Internat Verein Limnol 25:15-38

Bergamino L, Muniz P, Defeo O (2009) Effects of a freshwater canal discharge on polychaeta assemblages inhabiting an exposed sandy beach in Uruguay. Ecol Indic 9:584-587

Bhattacharya CG (1967) A simple method of resolution of a distribution into Gaussian components. Biometrics 23:115-135

Blake JA (2011) Revalidation of the genus Thoracophelia Ehlers, 1897, replacing Euzonus Grube, 1866 (Polychaeta: Opheliidae), junior homonym of Euzonus Menge, 1854 (Arthropoda: Diplopoda), together with a literature summary and updated listing of Thoracophelia species. Zootaxa 2807:65-68

Borzone CA, Souza JRB, Soares AG (1996) Morphodynamic influence on the structure of inter and subtidal macrofaunal communities of subtropical Sandy beaches. Braz J Nat Hist 69:565-577

Brazeiro A, Defeo O (1999) Effects of harvesting and density dependence on the demography of sandy beach populations: the yellow clam Mesodesma mactroides of Uruguay. Mar Ecol Prog Ser 182:127-135

Caetano CHS, Veloso VG, Cardoso RS (2003) Population biology and secondary production of Olivancillaria vesica vesica (Gmelin, 1791) (Gastropoda: Olividae) on a sandy beach in southeastern Brazil. J Molluscan Stud 69:67-73

Cardoso RS, Veloso VG, Caetano CHS (2003) Life history of Emerita brasiliensis (Decapoda: Hippidae) on two beaches with different morphodynamic characteristics. J Coast Res 35:392-401
Cassai C, Prevedelli D (1999) Fecundity and reproductive effort in Ophryotrocha labronica (Polychaeta: Dorvilleidae). Mar Biol 133:489-494

Choi JW, Lee JH (1997) Secondary production of a nereid species, Perinereis aibuhitensis in the intertidal mudflat of the West coast of Korea. Bull Mar Sci 60:517-528

Cotter E, O'Riordan RM, Myers AA (2003) A histological study of reproduction in the serpulids Pomatoceros triqueter and Pomatoceros lamarckii (Annelida: Polychaeta). Mar Biol 142:905-914

Crisp DJ (1984) Energy flow measurements. In: Holme NA, McIntyre AD (eds) Methods for the study of marine benthos. Blackwell, Oxford, pp 197-279

Cuzin-Roudy J (1993) Reproductive strategies of the Mediterranean krill, Meganyctiphanes norvegica and the Antarctic krill Euphausia superba (Crustacea: Euphausiacea). Invertebr Reprod Dev 23:105-114

Dales RP (1952) The larval development and ecology of Thoracophelia mucronata (Treadwell). Biol Bull 102:232-242

Dangott LJ, Terwilliger RC (1986) The role of extracellular hemoglobins in the oxygen consumption of the burrowing polychaete, Euzonus mucronata, (Treadwell). J Exp Mar Biol Ecol 97:193-204

Defeo O, Alava A (1995) Effects of human activities on long-term trends in sandy beach populations: the wedge clam Donax hanleyanus in Uruguay. Mar Ecol Prog Ser 123:73-82

Defeo O, Cardoso RS (2002) Macroecology of population dynamics and life history traits of the mole crab Emerita brasiliensis in Atlantic sandy beaches of South America. Mar Ecol Prog Ser 239:169-179

Defeo O, McLachlan A (2011) Coupling between macrofauna community structure and beach type: a deconstructive metaanalysis. Mar Ecol Prog Ser 433:29-41

Defeo O, Rueda M (2002) Spatial structure, sampling design and abundance estimates in sandy beach macroinfauna: some warnings and new perspectives. Mar Biol 140:1215-1225

Defeo O, Jaramillo E, Lyonnet A (1992) Community structure and intertidal zonation of the macroinfauna on the Atlantic coast of Uruguay. J Coast Res 8:830-839

Defeo O, Brazeiro A, Alava A, Riestra G (1997) Is sandy beach macroinfauna only physically controlled? Role of substrate and competition in isopods. Estuar Coast Shelf Sci 45:453-462

Dexter DM (1983) Community structure of intertidal sandy beaches in New South Wales, Australia. In: McLachlan A, Eramus T (eds) Sandy beaches as ecosystems. W. Junk, The Hague, pp 461-472

Dexter DM (1984) Temporal and spatial variability in the community structure of the fauna of four sandy beaches on south-eastern New South Wales. Aust J Mar Freshw Res 35:663-672

Fauchald K, Jumars PA (1979) The diet of worms: a study of polychaete feeding guilds. Oceanogr Mar Biol Annu Rev 17:193-284

Gayanilo FC, Pauly D (1997) FAO-ICLARM stock assessment tools (FISAT) reference manual. FAO Computerized Information Series (Fisheries), Rome

Giangrande A (1997) Polychaeta reproductive patterns, life cycles and life histories: an overview. Oceanogr Mar Biol Annu Rev 35:323-386

Gianuca NM (1987) Zonação e produção nas praias arenosas no litoral sul e sudeste do Brasil: síntese dos conhecimentos. ACIESP 54:313-332

Gillet P (1990) Biomasse, production et dynamique dês populations de Nereis diversicolor (Annélide polychète) de l'éstuaire de la Loire. Oceanol Acta 13:361-371

Gillet P, Torressani S (2003) Structure of the population and secondary production of Hediste diversicolor (O.F. Müller, 
1776), (Polychaeta, Nereidae) in the Loire estuary, Atlantic Coast, France. Estuar Coast Shelf Sci 56:621-628

Gillet P, Mouloud M, Duron C, Deutsch B (2008) Response of Nereis diversicolor population (Polychaeta, Nereididae) to the pollution impact-Authie and Seine estuaries (France). Estuar Cost Shelf Sci 76:201-210

Gordon MS (1960) Anaerobiosis in marine sandy beaches. Science 132:616-617

Horn Filho NO (2006) Granulometria das praias arenosas da Ilha de Santa Catarina, SC. Gravel 4:1-21

Jaramillo E, Gonzales M (1991) Community structure and zonation of the macroinfauna along a dissipative-reflective range of beach category in southern Chile. Stud Neotropical Fauna Environl 26:193-212

Kemp PF (1986) Direct uptake of detrital carbon by the depositfeeding polychaeta Euzonus mucronata (Treadwell). J Exp Mar Biol Ecol 99:49-61

Kemp PF (1988) Production and life history of a deposit feeding polychaete in an atypical environment. Estuar Coast Shelf Sci 26:437-446

Kevrekidis T (2005) Population dynamics, reproductive biology and productivity of Streblospio shrubsolii (Polychaeta: Spionidae) in different sediments at low salinities in a Mediterranean Lagoon (Monolimni Lagoon, Northern Aegean). Int Rev Hydrobiol 90:100-121

Klesch WL (1970) The reproductive biology and larval development of Laeonereis culveri Webster (Polychaeta: Nereidae). Contrib Mar Sci 15:71-85

Knox CA (1977) The role of polychaetes in benthic soft-bottom communities. In: Reish DJ, Fauchauld K (eds) Essays on polychaetous annelids in memory of Dr. Olga Hartman. Allan Hancock Foundation, University of Southern California, Los Angeles

Leal PC (1999) Sistema praial Moçambique—Barra da lagoa, Ilha de Santa Catarina, SC, Brasil: Aspectos morfológicos, morfodinâmicos, sedimentológicos e ambientais. Dissertation, University Santa Catarina, Brazil

Leber KM (1982) Seasonality of macroinvertebrates on a temperature, high wave, energy sandy beach. Bull Mar Sci 32:86-98

MacCord FS, Amaral ACZ (2007) The reproductive cycle of Scolelepis goodbodyi (Polychaeta, Spionidae). Mar Biol 151:1009-1020

Martin JP, Bastida R (2006) Population structure, growth and production of Laonereis culveri (Nereididae: Polychaeta) in tidal flats of Río de la Plata estuary, Argentina. J Mar Biol Assoc UK 86:235-244

McLachlan A, Brown AC (2006) The ecology of sandy shores. Academic Press, London

Neves LP, Silva PSR, Bemvenuti CE (2007) Zonation of benthic macrofauna on Cassino beach, Southernmost Brazil. Braz J Oceanogr 55:293-307

Newell R (1965) The role of detritus in the nutrition of two marine deposit feeders, the prosobranch Hydrobia ulvae and the bivalve Macoma baltica. Proc Zool Soc Lond 144:25-45

Omena EP, Amaral ACZ (2000) Population dynamics and secondary production of Laeonereis acuta (Treadwell, 1923) (Nereididae: Polychaeta). Bull Mar Sci 67:421-431

Orensanz JM, Gianuca NM (1974) Contribuição ao conhecimento dos anelídeos poliquetas do Rio Grande do Sul, Brasil. I-Lista sistemática preliminar e descrição de três novas espécies. Comunicação do Museu de Ciências PUCRGS 4:1-37

Pagliosa PR, Lana PC (2000) Population dynamics and secondary production of Nereis oligohalina (Nereidade: Polychaeta) from a subtropical marsh in southeast Brazil. Bull Mar Sci 67:259_ 268
Pauly D (1983) Some simple methods for the assessment package of tropical fish stock. FAO Fisheries Technical Paper 234

Pauly D, Gaschutz G (1979) A simple method for fitting oscillating length growth data, with a program for pocket calculators. International council for the exploration of the Sea, Council Meeting, Demersal Fish Cttee

Pauly D, Munro JL (1984) Once more on the comparison of growth in fish and invertebrate. ICLARM Fishbyte 2:21-33

Pereira MLM (2004) Estudo da dinâmica das águas do canal da barra, Barra da Lagoa, Florianópolis, SC. Dissertation, University Santa Catarina

Petracco M, Cardoso RS, Corbisier TN (2010) Population biology of Excirolana armata (Dana, 1853) (Isopoda, Cirolanidae) on an exposed sandy beach in Southeastern Brazil. Mar Ecol $31: 330-340$

Petti MAV, Nonato EF, Paiva PC (1996) Trophic relationships between polychaetes and brachyuran crabs on the southeastern Brazilian coast. Braz J Oceanogr 44:9-21

Prevedelli D, Simonini R (2003) Life cycles in brackish habitats: adaptive strategies of some polychaetes from the Venice lagoon. Oceanol Acta 26:77-84

Roff DA (1992) The evolution of life histories: theory and analysis. Chapman \& Hall, New York

Santos PJP (1994) Population dynamics and production of Scolelepis gaucha (Polychaeta: Spionidae) on the sandy beaches of southern Brazil. Mar Ecol Prog Ser 110:159-165

Schlacher TA, Schoeman DS, Dugan J, Lastra M, Jones A, Scapini F, McLachlan A (2008) Sandy beach ecosystems: key features, sampling issues, management challenges and climate change impacts. Mar Ecol 29:70-90

Schneider DC, Harrington BA (1981) Timing and shore bird migration in relation to pray depletion. Auk 98:801-811

Seike K (2008) Burrowing behavior inferred from feeding traces of the Opheliid polychaete Euzonus sp. as response to beach morphodynamics. Mar Biol 153:1199-1206

Silva PSR, Neves LP, Bemvenuti CE (2008) Temporal variation of Sandy beach macrofauna at two sites with distinct environmental conditions on Cassino beach, extreme southern Brazil. Braz J Oceanogr 56:257-270

Simó DH, Horn Filho NO (2004) Caracterização e distribuição espacial das "ressacas" e áreas de risco na ilha de Santa Catarina, SC, Brasil. Gravel 2:93-103

Souza JRG, Borzone CA (2000) Population dynamics and secondary production of Scolelepis squamata (Polychaeta: Spionidae) in an exposed sandy beach of Southern Brazil. Bull Mar Sci 67:221-233

Souza JRG, Borzone CA (2007) Population dynamic and secondary production of Euzonus furcifera Ehlers (Polychaeta: Opheliidae) in an exposed sandy beach of Southern Brazil. Braz J Zool 24:1139-1144

Souza JRG, Gianuca NM (1995) Zonation and seasonal variation of the intertidal macrofauna on a sandy beach of Paraná State, Brazil. Sci Mar 59:103-111

Taheri M, Seyfabadi J, Abtahi B, Foshtomi MY (2009) Population changes and reproduction of an alien spionid polychaeta, Streblospio gynobranchiata, in shallow waters of the south Caspian Sea. Mar Biodivers Rec 2:1-5

Tumbiolo M, Downing JA (1994) An empirical model for the prediction of secondary production in marine benthic invertebrate populations. Mar Ecol Prog Ser 114:165-174

Veloso VG, Cardoso RS (1999) Population biology of the mole crab Emerita brasiliensis (Decapoda: Hippidae) at Urca Beach, Brazil. J Crust Biol 19:147-153

Veloso VG, Caetano CHS, Cardoso RS (2003a) Composition, structure and zonation of intertidal macroinfauna in relation to 
physical factors in microtidal sandy beaches in Rio de Janeiro states, Brazil. Sci Mar 67:393-402

Veloso VG, Cardoso RS, Petracco M (2003b) Secondary production of the intertidal macrofauna of Prainha Beach, Brazil. J Coast Res 35:385-391
Wilber DH, Clarke DG (1998) Estimating secondary production and benthic consumption in monitoring studies: a case study of the impacts of dredged material disposal in Galveston Bay, Texas. Estuar 21:230-245 